\title{
The Cultural Expressions and Representation of National Identity- A Study of the Indian Singing Reality Television Show "Sa Re Ga Ma Pa"
}

\author{
Taranjeet Kaur Chawla ${ }^{1}$ Shiv Shankar Sharma² Rayaz Hassan ${ }^{3}$ \\ ${ }^{1}$ Ph.D. Research Scholar, Department of Journalism and Mass Communication, Manipal \\ University Jaipur, Rajasthan-India. ORCID id: oooo-ooo2-5336-1964 \\ Email id:ms.kauron@gmail.com \\ ${ }^{2}$ Ph.D. Research Scholar, Department of Journalism and Mass Communication, Manipal \\ University Jaipur, Rajasthan-India. Email id: shiv.sharma6969@gmail.com \\ 3 Associate Professor, Department of Journalism and Mass Communication, Manipal \\ University Jaipur, Rajasthan-India. Email id: rayaz.hassan@jaipur.manipal.edu
}

\begin{abstract}
This paper aims to understand the narrative structure of Indian singing reality television show to identify the representation of national identity. By focusing on the "Sa Re Ga Ma Pa" show format, this paper has followed the work of Vladimir Propp to examine the cultural expressions with the sequential development of the narrative plot. The convergent parallel mixed method has been using to collect quantitative and qualitative data. While using the Likert scale, the reliability of the questionnaire has been calculated and reported Cronbach's alpha coefficient for internal consistency reliability. The quantitative data has gathered from 205 respondents and 99 episodes aired from 2017 to 2019 have analysed in qualitative data, which is followed by data analysis through IBM SPSS Statistics. By analysing the quantitative and qualitative data this paper finds that the cultural expressions reveal the notion of national identity through the representation of 'ordinary' people and emphasis on performances by focusing on the structured format of Indian reality television. The paper indicates the ways where the viewers of the society can connect with cultural expressions through the genre of reality television.
\end{abstract}

Keywords: Cultural expressions, Indian reality television, Narrative analysis, National identity, Sa Re Ga Ma Pa, Vladimir Propp.

\section{Introduction}

In everyday life, television performs as a primary medium and helps to develop the nation through address mass audiences (Edensor 2002, 7). In addition, with the development of satellite and cable television, most of the television programmes are still scheduled on a national basis, and those TV programmes are most popular which are liked by large numbers of national viewers (Edensor 2002, 98). Reality television has gathered and maintained the attention of viewers around the world since the 1980s (Lundy, Ruth, and Park, 2008), and become a 'successful' part of television in the 1990s

(c) AesthetixMS 2021. This Open Access article is published under a Creative Commons Attribution Non-Commercial 4.0 International License (http://creativecommons.org/licenses/by-nc/4.o/), which permits non-commercial re-use, distribution, and reproduction in any medium, provided the original work is properly cited. For citation use the DOI. For commercial re-use, please contact editor@rupkatha.com. 
and 200os (Hill Annette, 2005). The 'continuity' of reality television explores 'nationhood' day by day (V.Cann 2013, 730).

The nature of reality TV means in the natural setting with the presentation of 'non-actors' and 'work without scripts', reality television claims depicted as spontaneous truthful documentation of 'natural reality' (Bagley, 2001, 1). Ordinary people serve as the main characters in reality television programme format (Reiss \& Wiltz 2004, 370). Klaus \& Luecke (2003) emphasize that reality TV as a genre consists of different subgenres and divides shows into two main groups that are narrative reality TV and second is performative reality TV. Barton (2009) concentrated exclusively on 'competition-based reality shows', which include programs that create a competitive context between the participants of the shows.

The singing Indian reality TV show "Sa Re Ga Ma Pa" became a pioneer in becoming a longrunning Indian reality television show which started airing in 1995 on Zee TV. The ability of singing reality show format to make reality television remarkable in India, which consequently makes it an interesting field of research. This study seeks to understand the nation-specific elements that represent the notion of the nation with cultural expressions in the "Sa Re Ga Ma Pa" Indian singing reality television show format. According to the format, experts from the field of music used to judge the contestants, and score them based on the performance. Later, the show introduced judges as mentors of different teams. The results and eliminations are dependent on pubic voting. Using this show, the present study focuses on the format of the show in which reality television performed as a 'cultural medium' and offers cultural expressions to represent national identity.

\section{Culture and National Identity}

It is an ambivalence that emerges from a growing awareness to pay attention to the notion of nation in reality television because Homi K Bhabha proposed that nationalism has to be understood with 'large cultural system' and system of 'cultural significance' as the representation of social life (1990, 1-2). The work of Homi K Bhabha (1990) contributed to understanding the sense of the nation as one of the major structures of ideological ambivalence within the cultural representations of 'modernity'. Billig suggests in Banal Nationalism (1995) that the 'whole complex of beliefs, assumptions, habits, representations, and practices' which (re)produce national identity are reproduced in the banal realm of everyday as part of the 'endemic condition' of nations. According to Billig, the reproduction of national identity is grounded in the habitual assumptions about belonging that permeate the media, where the term 'we' is un reflexively used as a signifier of 'us' as members of the nation. Edensor (2002) expands his analysis of national identity to popular culture and everyday life, he focused upon institutionalized schedules, habitual routines, collective synchronicities, and serialized time-spaces to develop an argument that quotidian, cyclical time is integral to national identity.

Fiske (1989) and Willis (1990) stressed further the importance to consider the cultural contexts. In the representation of national identity, culture has been considered a prominent part. Hutchinson (1994) considered the relationship between culture and national identity and mentioned political definitions of nationalism often display an image of an instrumental, bureaucratic state, which has put forward the contrary idea of "cultural nationalism". The national and cultural context may be characterized by a group of interested people and experts who believe in a range of cultural forms and practices. In the constitution of national identities, cultural ingredients can count as an important element (Smith, 1998). 
It is one thing to identify theoretically the role of television to form a national identity, but it is another thing to locate in the reality television show. Each genre of reality television programming relates some elements. The popularity of given elements has some relevance with audience beliefs and values (Nachbar \& Lause, 1992). The forms of cultural elements and values are integral to the symbolic representation of Indian society. The Indian cultural history is associated with rituals and traditional performances. Goffman has mentioned in his work that "humans use culture in interactions" and semiotic activity was fundamental to social interaction (Goffman, 1974).

\section{Review of Literature}

After attempting to find previous research on the Indian singing reality television show format with a focus on national representations, we came to the conclusion that this subject of research is needed to explore in India. There are studies considering Indian reality television in the context of education, age, gender and family type, perceptions, the social attitude of rural school children (Dixit, 2013), (Mathur, 2014). While others have examined issues of reality show participants, problems faced by unguided learners. Some studies dealt with the influence of reality television on youth and parental mediation and their attitude towards children's television viewing (Trivedi, 2016), (N.Boobalakrishnan, 2016), (Kumar, 2017) changed in television content (Namjoshi, 2015). Another scholar concentrated on the impact of soap operas and reality shows on viewers (Khanchandani, 2018). However, the phenomenon of Indian reality television still needs to more explore. Nonetheless, researchers have reviewed several research articles which have a certain degree of relevance to our enquiry.

Stewart (2019) studied "Live tweeting, reality TV and the nation", and argues that the livetweeting of reality television allows the creation of an imagined community, bounded by national borders. He mentioned that the television industry is using social media to reconstruct a live national viewing community around reality television, and suggested that this practice makes visible understandings of national cultural identity and the ways that this is expressed both by the networks and by the viewers themselves. Cann V. (2013) explored the ways in which reality TV constructs the nation as part of everyday nationhood. She focused on how reality TV makes a claim 'the real' through authenticity, particularly concerning performances of the self (and more specifically, the national self). Cann suggested that through media discourse, particularly in the form of television, we can identify one of the key ways in which the concept of the nation is normalized. Malko A. (2013) focused on analysing the narrative structures of the Survivor format productions in Sweden, the USA, and Russia in pursuance of revealing representations and reproductions of the nations. A structural narrative analysis with a comparative approach exposed the nation-specific elements that reproduce the idea of a nation. Malko argued that national expressions are in general based on traditions and rituals of the nations. Potter A. (2013) analyses Prank Patrol (Australia's first dedicated free-to-air children's channel ABC3's most popular program was a local version of the transnational reality format). The results show that contemporary children's reality television distributed by public service media may be expressing the goals of cultural nationalism in ways that previously have been accorded primarily to children's drama. Price E. (2010) analysed the use of popular Australian myth in 'reality' formats by charting narrative and character construction as an 'illusory everyday', with reference to Bondi Rescue (Cordell Jigsaw). She examined the representation of Australian identity through both myth and construction in 'reality TV' as the perpetuation of a cultural simulation. Aslama M., Pantti M. (2007) used a Finnish adventure show Extreme Escapades as a case, and argued that national television still plays an important role in constructing national identities; that reality television as a popular 
cultural product should be viewed in the context of "banal nationalism" and that the genre may indeed redefine the meaning of national television in the globalized media sphere. In the article Cultural Identity, Soap Narrative, and Reality TV, Turner G. (2005) discussed the issue of locally produced docusoaps being threatened by the global formats of reality TV programmes, which were originally brought up by Latin-American scholars. He examined similarities and differences between the two formats and concluded that both construct communities through representative narratives, which is the central feature of these formats. Turner also concludes that these transnational formats are, in fact, flexible while illustrating how narratives of local everyday life can arrange nationally appealing and familiar TV shows.

\section{Aims of the Study}

- To understand the nation-specific elements those represent the notion of the nation in Indian singing reality television show.

- To study how cultural expressions and national identity are represented in a singing Indian reality TV show format.

- $\quad$ To analyse the format of Indian singing reality television show.

\section{Methodology}

Narrative analysis is useful in media studies to identify the 'cultural implications' of television programming. The present study has applied a syntagmatic approach, which is based on the formalist work of Vladimir Propp (1968). In his Morphology of the Folktale (1968), he identified and analysed basic narrative components of Russian folk tales. Propp helps us understand what happens in a story, how plots are structured. This study established the base structure of the reality singing show format "Sa Re Ga Ma Pa" and examined the sequential development of the narrative plot. Researchers have observed the functions of events in the show in order to create templates that served as a tool to consequently establish a common structural pattern of singing reality television shows.

\section{Research Design}

\section{Convergent Parallel Mixed Methods Design}

The convergent mixed methods approach is probably the most familiar of the basic and advanced mixed methods strategies. According to this approach, we have collected both quantitative and qualitative data, analysed them separately, and then compared the results to see if the findings confirm or disconfirm each other. This research work seeks to overarching research aims, in two steps. First, a qualitative study applying narrative analysis of the shows is conducted to get insights into structure narrative texts and cultural codes of the Indian singing reality television genre. Building upon the results of this research work included with review of literature which identified in a reality television context, in a second step quantitative study is conducted to further analyse these contexts with their determinants and consequences. A combination of qualitative and quantitative research enables a thorough analysis of narrative to complete the motive to identify the representation of national identity within Indian singing reality television show. 


\section{Likert Scale (1-5)}

A Likert rating scale measurement has been used for measuring that requires an individual to respond to a series of statements by indicating whether respondents strongly agree, agree, neutral, disagree, or strongly disagree. According to Hornig (2010:227), the Likert scale consists of a series of questions answered on a numerical, 5-or 7-point, agree-or-disagree scale.

\section{Reliability}

Cronbach's Alpha (1951) is the most commonly used reliability coefficient as a generalized measure of the internal consistency of the construct indicators (Peter 1979). While using the Likert scale, it is important to calculate and report Cronbach's alpha coefficient for internal consistency reliability. As per the requirement of the study, a Likert scale-based questionnaire has given to the twenty students for the pilot study, while analysing in SPSS the Cronbach's alpha was found to be 0.79, which suggested good consistency. Later, the questionnaire has shared with the students of film and television studies. The reliability test has been 0.80 indicating a strong consistent reliable questionnaire (George and Mallery, 2003). The mean, variance, standard deviation, item wise correlations for all items were also calculated which have shown very good results consistent with the accepted standards (See Table 2 and $2 \mathrm{a}$ ).

\section{Sample}

As the universe for the study runs into hundreds of shows over the years, we developed criteria for selecting the representative sample for a qualitative study.

1) The show selected for the analysis is $\mathrm{Sa} \operatorname{Re} \mathrm{Ga} M a \mathrm{~Pa}$ (Singing, talent, and competition) is an original Indian series.

2) The show which is running for long and have enormous popularity, and several seasons of the show that has been made almost every year.

3) The seasons are available on their broadcast network application- Zee5.

4) The analysis is based on 99 episodes that were aired from 2017 to 2019. "Sa Re Ga Ma Pa L'il Champs" 2017 aired on 25 February 2017 on Zee TV in back to school format, in which contestant represents their schools. 27th season of "Sa Re Ga Ma Pa" 2018 aired on 13th October 2018 with the thought of music for all, the grand finale telecasted on 27th January 2019.

5) For a quantitative study, a survey of opinions has been received through a questionnaire from 205 students of film and television studies from different colleges affiliated with the University of Mumbai, Maharashtra. This was done over 45 days within the month of November and December 2020.

Table 1: Showing frequency and percentage of agreement with the variables constructed as items in the questionnaire;

\begin{tabular}{|c|c|c|c|c|c|c|c|c|c|c|c|}
\hline \multirow[t]{2}{*}{$\begin{array}{c}\text { Item } \\
\text { No. }\end{array}$} & \multirow[t]{2}{*}{ Question } & \multicolumn{2}{|c|}{$\begin{array}{l}\text { Strongly } \\
\text { Agree }\end{array}$} & \multicolumn{2}{|c|}{ Agree } & \multicolumn{2}{|c|}{ Neutral } & \multicolumn{2}{|c|}{ Disagree } & \multicolumn{2}{|c|}{$\begin{array}{l}\text { Strongly } \\
\text { Disagree }\end{array}$} \\
\hline & & Freq. & $\%$ & Freq. & $\%$ & Freq. & $\%$ & Freq. & $\%$ & Freq & $\%$ \\
\hline 1 & $\begin{array}{l}\text { The cultural } \\
\text { expressions in singing }\end{array}$ & 30 & 14.6 & 124 & 60.5 & 42 & 20.5 & 9 & 4.4 & $\mathrm{o}$ & o \\
\hline
\end{tabular}




\begin{tabular}{|c|c|c|c|c|c|c|c|c|c|c|c|}
\hline & $\begin{array}{l}\text { reality television } \\
\text { show formats by } \\
\text { charting narrative } \\
\text { and characters } \\
\text { construct the } \\
\text { impressions of } \\
\text { national identity. }\end{array}$ & & & & & & & & & & \\
\hline 2 & $\begin{array}{l}\text { Indian music and } \\
\text { singing reality } \\
\text { television show } \\
\text { format reveals the } \\
\text { representation of the } \\
\text { nation. }\end{array}$ & 18 & 8.8 & 134 & 65.4 & 38 & 18.5 & 14 & 6.8 & 1 & 0.5 \\
\hline 3 & $\begin{array}{l}\text { Indian singing reality } \\
\text { television performed } \\
\text { as a cultural medium, } \\
\text { in which televisual } \\
\text { communication is the } \\
\text { method of ritualized } \\
\text { arbitration of cultural } \\
\text { reality. }\end{array}$ & 83 & 40.5 & 98 & 47.8 & 21 & 10.2 & 2 & 1.0 & 1 & 0.5 \\
\hline 4 & $\begin{array}{l}\text { A sense of national } \\
\text { identity cannot be } \\
\text { found in one thing, it } \\
\text { can be dynamic with } \\
\text { the mix of cultural } \\
\text { values, images, } \\
\text { symbols, and } \\
\text { practices. }\end{array}$ & 13 & 6.3 & 107 & 52.2 & 60 & $29 \cdot 3$ & 23 & 11.2 & 2 & 1.0 \\
\hline 5 & $\begin{array}{l}\text { The songs and } \\
\text { performances of } \\
\text { participants in } \\
\text { singing reality } \\
\text { television shows offer } \\
\text { cultural expressions } \\
\text { to represent national } \\
\text { identity. }\end{array}$ & 54 & 26.3 & 105 & 51.2 & 38 & 18.5 & 7 & 3.4 & 1 & 0.5 \\
\hline 6 & $\begin{array}{l}\text { In the form of } \\
\text { singing reality } \\
\text { television, we can } \\
\text { identify the key ways } \\
\text { in which the concept } \\
\text { of the nation is } \\
\text { constructed. }\end{array}$ & 57 & 27.8 & 104 & 50.7 & 35 & 17.1 & 7 & 3.4 & 2 & 1.0 \\
\hline 7 & $\begin{array}{l}\text { Indian singing reality } \\
\text { television represents } \\
\text { the nation through } \\
\text { cultural expressions } \\
\text { such as cultural } \\
\text { values, traditions, } \\
\text { festivals which are } \\
\end{array}$ & 46 & 22.4 & 108 & 52.7 & 43 & 21.0 & 7 & 3.4 & 1 & 0.5 \\
\hline
\end{tabular}




\begin{tabular}{|c|c|c|c|c|c|c|c|c|c|c|c|}
\hline & $\begin{array}{l}\text { inspired by national } \\
\text { audiences. }\end{array}$ & & & & & & & & & & \\
\hline 8 & $\begin{array}{l}\text { The singing reality } \\
\text { show is sending out a } \\
\text { strong message of all- } \\
\text { inclusiveness and } \\
\text { standing up against } \\
\text { discrimination over } \\
\text { caste, creed, colour, } \\
\text { community, religion } \\
\text { and sexuality, only } \\
\text { focuses its spotlights } \\
\text { on talent. }\end{array}$ & 39 & 19.0 & 110 & 53.7 & 45 & $\begin{array}{c}22 . \\
0\end{array}$ & 10 & 4.9 & 1 & 0.5 \\
\hline 9 & $\begin{array}{l}\text { The narrative of } \\
\text { singing television } \\
\text { shows succeed in } \\
\text { sharing cultural } \\
\text { elements through } \\
\text { performance of } \\
\text { participants. }\end{array}$ & 49 & 23.9 & 111 & 54.1 & 32 & 15.6 & 12 & $5 \cdot 9$ & 1 & 0.5 \\
\hline 10 & $\begin{array}{l}\text { The national identity } \\
\text { is positively } \\
\text { associated with } \\
\text { cultural expressions. }\end{array}$ & 29 & 14.1 & 118 & 57.6 & 49 & 23.9 & 8 & 3.9 & 1 & 0.5 \\
\hline 11 & $\begin{array}{l}\text { The "Sa Re Ga Ma } \\
\text { Pa" show is usually } \\
\text { considered as a } \\
\text { festival of music with } \\
\text { full of hope and } \\
\text { energy with the core } \\
\text { theme of 'Music for } \\
\text { all'. }\end{array}$ & 18 & 8.8 & 108 & 52.7 & 63 & 30.7 & 15 & $7 \cdot 3$ & 1 & 0.5 \\
\hline 12 & $\begin{array}{l}\text { This show carries the } \\
\text { idea of pluralism, } \\
\text { equal respect to all } \\
\text { religions is can count } \\
\text { as notion of nation } \\
\text { within the society. }\end{array}$ & 18 & 8.8 & 115 & 56.1 & 55 & $\begin{array}{c}26 . \\
8\end{array}$ & 16 & 7.8 & 1 & 0.5 \\
\hline
\end{tabular}

Table 2: Item-Analysis (Cronbach's alpha) from SPSS output

Scale Statistics

\begin{tabular}{|c|c|c|c|}
\hline Mean & Variance & Std. Deviation & N of Items \\
\hline 25.7854 & 27.111 & 5.20678 & 12 \\
\hline
\end{tabular}

\section{Summary Item Statistics}

\begin{tabular}{|l|r|r|r|r|r|r|r|}
\hline & Mean & Minimum & Maximum & Range & $\begin{array}{c}\text { Maximum / } \\
\text { Minimum }\end{array}$ & Variance & $\begin{array}{c}\text { N of } \\
\text { Items }\end{array}$ \\
\hline Item Means & 2.149 & 1.732 & 2.483 & .751 & 1.434 & .041 & 12 \\
Item Variances & .598 & .508 & .676 & .168 & 1.332 & .004 & 12
\end{tabular}




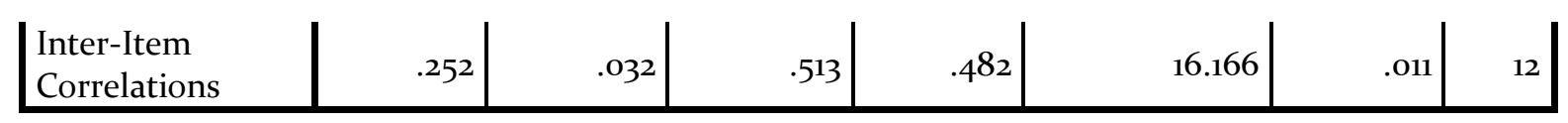

Reliability Statistics

\begin{tabular}{|r|r|r|}
\hline Cronbach's Alpha & $\begin{array}{c}\text { Cronbach's Alpha Based on } \\
\text { Standardized Items }\end{array}$ & N of Items \\
\hline .802 & .802 & \\
\hline
\end{tabular}

Item-Total Statistics

\begin{tabular}{|l|r|r|r|r|r|}
\hline & $\begin{array}{r}\text { Scale Mean if } \\
\text { Item Deleted }\end{array}$ & $\begin{array}{r}\text { Scale Variance } \\
\text { if Item Deleted }\end{array}$ & $\begin{array}{c}\text { Corrected Item- } \\
\text { Total Correlation }\end{array}$ & $\begin{array}{c}\text { Squared Multiple } \\
\text { Correlation }\end{array}$ & $\begin{array}{c}\text { Cronbach's Alpha if } \\
\text { Item Deleted }\end{array}$ \\
\hline Q1 & 23.6390 & 23.497 & .450 & .273 & .788 \\
Q2 & 23.5366 & 22.868 & .533 & .355 & .780 \\
Q3 & 24.0537 & 23.727 & .407 & .261 & .791 \\
Q4 & 23.3024 & 22.320 & .537 & .382 & .779 \\
Q5 & 23.7805 & 24.260 & .283 & .146 & .803 \\
Q6 & 23.7951 & 23.203 & .408 & .217 & .792 \\
Q7 & 23.7171 & 22.312 & .566 & .392 & .776 \\
Q8 & 23.6439 & 22.985 & .458 & .309 & .787 \\
Q9 & 23.7366 & 21.803 & .604 & .438 & .772 \\
Q10 & 23.5951 & 24.017 & .351 & .196 & .796 \\
Q11 & 23.4049 & 24.232 & .303 & .134 & .801 \\
Q12 & 23.4341 & 23.061 & .468 & .332 & .786 \\
\hline
\end{tabular}

Table 2.a.: Item-Statistics of $\mathrm{N}=205$ Item Statistics of Respondent's Answers

\begin{tabular}{|l|r|r|r|}
\hline & \multicolumn{1}{|c|}{ Mean } & Std. Deviation & \multicolumn{1}{c|}{$\mathrm{N}$} \\
\hline Q1 & 2.1463 & .71266 & 205 \\
Q2 & 2.2488 & .72866 & 205 \\
Q3 & 1.7317 & .72167 & 205 \\
Q4 & 2.4829 & .81406 & 205 \\
Q5 & 2.0049 & .79519 & 205 \\
Q6 & 1.9902 & .82242 & 205 \\
Q7 & 2.0683 & .78292 & 205 \\
Q8 & 2.1415 & .79489 & 205 \\
Q9 & 2.0488 & .82102 & 205 \\
Q10 & 2.1902 & .73957 & 205 \\
Q11 & 2.3805 & .76799 & 205 \\
Q12 & 2.3512 & .76924 & 205 \\
\hline
\end{tabular}

\section{Analysis and Discussion}

One may argue that the audition, judges, competition, and elimination in reality television are premised upon the expectations of the Indian market at which they are aimed. This flow of moving images and show format is designed to appeal an Indian audience but also bear powerful traces of Indian ideologies. Because television appeals desires and aspirations that are related to the national interest, it is important to note that the television culture is one of the parts of our entertainment world. Such shows are therefore important cultural forms that represent the nation through cultural expressions such as cultural values, traditions, festivals that are inspired by national 
audiences. By analysing theme, structure, and narrative, we firstly analysed the episodes that represent national symbols within the show by considering performances. Secondly, we assessed cultural expressions to highlight the notion of nation, then explored how this show has significantly important for ordinary people and celebrity. Furthermore, we have analysed the cultural context associated with the show.

\section{'Swaras' and 'Sargam'}

In India, Sa Re Ga Ma Pa Dha Ni refers to the beginning of "Swaras" and "Sargam". Hence, the show indicates articulated way to start singing. The seven notes of the musical scale in Indian classical music are shadja, rishabha, gandhara, madhyama, panchama, dhaivata and nishada. These seven swaras are shortened to Sa, Ri (Carnatic) or Re (Hindustani), Ga, Ma, Pa, Dha, and Ni. Collectively these notes are known as the sargam (the word is an acronym of the consonants of the first four swaras). These swaras are the pillars of the music. Therefore, this show is usually considered as a festival of music full of hope and energy with the core theme of 'Music for all'. It is worth mention that this show is sending out a strong message of all-inclusiveness and standing up against discrimination over caste, creed, colour, community, religion, and only focuses its spotlights on talent. Due to the relational nature of nationality, whereby the viewers are constantly reminded that this is an Indian musical reality television show and is able to connect themselves in relation to Indians. Barker says, 'imagining "us" as "one" is part of the process of nation-building and there is no medium which has been able to speak to as many people in pursuit of that goal as television' (Barker, 1999, 5).

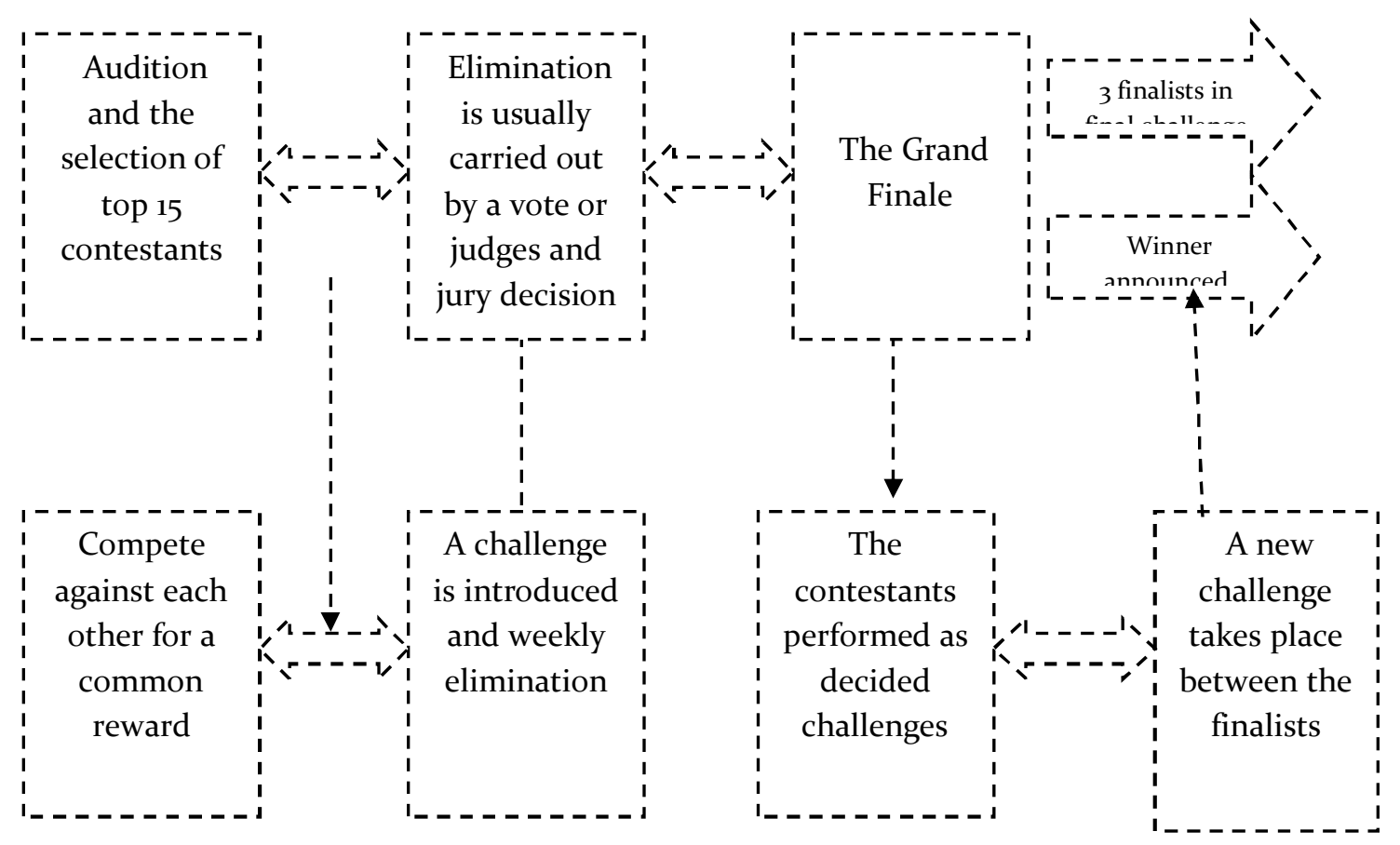

Figure 1: The Narrative Structure of Indian Singing Reality Television Show "Sa Re Ga Ma Pa"

\section{Guru (Teacher) - Shishya (Student) Tradition}

The classical art form in music and dance in India has always been taught under the 'Guru-Shishya parampara' - The Teacher - Student tradition which is as old as the Sanskrit epics of our history 
'Ramayan' and 'Mahabharata' in India. In the case of singing reality television, the role of mentors or Guru found a significant factor in the success of participants. The main debate within GuruShishya relationship reflected in the reality shows were the difference between traditional and modern methods of teaching. The selected contestants have to stay with the co-contestants till the elimination. In the episodes of $\mathrm{Sa} \operatorname{Re} \mathrm{Ga} M a \mathrm{~Pa}$, the contestants trained by experts in the field of music, were the jury members in the show. The jury and judges scored them and taught them the music skills. The jury members bring as a mentor, who discovered the talent of contestants. Finally, the "Jury challenge" episodes portrayed the performance of the contestants as a means of exams where the jury and judges were given the rewards on "Blockbuster performance". Additionally, after completing the jury challenge, contestants claimed their rewards and fulfill their wishes from the jury members. This is portrayed as a modern method of learning where the relationship reflected friendliness among the jury and contestants. The shows illustrated the relationship briefly, as the judges/masters/mentors/jury members/ coaches were considered as Gurus in the shows who were trained the contestants for rewards.

Table 3: Proposed Structure of "Sa Re Ga Ma Pa"

\begin{tabular}{|c|c|c|c|}
\hline $\begin{array}{l}\text { Sr. } \\
\text { No. }\end{array}$ & $\begin{array}{l}\text { Proposed } \\
\text { Structure }\end{array}$ & "Sa Re Ga Ma Pa L'il Champs" 2017 & "Sa Re Ga Ma Pa" 2018 \\
\hline 1. & $\begin{array}{l}\text { Contestants are } \\
\text { brought together } \\
\text { to compete for } \\
\text { common reward }\end{array}$ & $\begin{array}{l}\text { Introduction of the rules, core } \\
\text { theme and audition round Began- } \\
\text { Core thought is (suro ka Dangal). } \\
\text { In a 'Back to School' format. In the } \\
\text { auditions round, they have 1oo } \\
\text { seconds to impress the three judges } \\
\text { and the 30-members of the grand } \\
\text { jury. }\end{array}$ & $\begin{array}{c}\text { Introduction of the rules, core theme } \\
\text { and audition round Began- } \\
\text { Core thought of music for all - } \\
\text { \#MusicSeBaneHum. } \\
\text { Every contestant must achive more } \\
\text { than } 50 \% \text { of the score in their favour } \\
\text { from the members of the jury to get } \\
\text { selected at the preliminary level. }\end{array}$ \\
\hline 2. & $\begin{array}{l}\text { Challenge; } \\
\text { reward } \\
\text { introduced }\end{array}$ & $\begin{array}{l}\text { Top } 15 \text { contestants have been } \\
\text { selected after mega-audition. } \\
\text { 'Student of the Week'- the best } \\
\text { performer. } \\
\text { Due to the popularity of the show, } \\
\text { they had taken another audition in } \\
\text { the mid-season. From the second } \\
\text { audition five contestants were } \\
\text { selected. }\end{array}$ & $\begin{array}{l}\text { Steal Card- contestant can get direct } \\
\text { entry in top } 15 . \\
\text { Top } 15 \text { contestants have been } \\
\text { selected after mega-audition. } \\
\text { Every week- the best performer, The } \\
\text { best is declared safe from next week's } \\
\text { elimination }\end{array}$ \\
\hline 3. & $\begin{array}{l}\text { The contestants } \\
\text { are normally } \\
\text { performed as } \\
\text { decided } \\
\text { challenges. }\end{array}$ & $\begin{array}{l}\text { A panel of } 30 \text { jury members, who are } \\
\text { experts from the music industry, } \\
\text { gives task and challenges to the } \\
\text { contestants. }\end{array}$ & $\begin{array}{l}\text { Contestants normally divided into } \\
\text { groups, According to the selection of } \\
\text { Judges and choices of the contestant. }\end{array}$ \\
\hline 4. & $\begin{array}{l}\text { Weekly } \\
\text { competitions }\end{array}$ & $\begin{array}{l}\text { Weekly challenge from jury } \\
\text { members and judges of the show. }\end{array}$ & $\begin{array}{l}\text { Weekly challenge from jury } \\
\text { members and judges of the show. }\end{array}$ \\
\hline 5 . & $\begin{array}{l}\text { Elimination by } \\
\text { vote }\end{array}$ & $\begin{array}{l}\text { Vote appealing and elimination on } \\
\text { the bases of votes }\end{array}$ & $\begin{array}{l}\text { Those who have fewer votes as } \\
\text { compared to other contestant will } \\
\text { get eliminated. }\end{array}$ \\
\hline 6. & $\begin{array}{c}\text { Number of } \\
\text { contestants } \\
\text { below certain }\end{array}$ & $\begin{array}{c}\text { Number of contestants under 10, } \\
\text { new challenges introduced and } \\
\text { second audition began } \\
\end{array}$ & $\begin{array}{c}\text { Number of contestants } 8 \text {; challenges } \\
\text { introduced; } 1 \text { contestant eliminated } \\
\text { weekly. }\end{array}$ \\
\hline
\end{tabular}




\begin{tabular}{|c|c|c|c|}
\hline & $\begin{array}{c}\text { point; new game } \\
\text { plan }\end{array}$ & \\
\hline 7. & Final challenge & 4 finalists in final challenge & 3 finalists in final challenge \\
\hline 8. & Grand Finale & $\begin{array}{c}\text { Two winners announced, Anjali and } \\
\text { Shreyan won the grand finale. }\end{array}$ & $\begin{array}{c}\text { "Ishita vishvkarma" won the title and } \\
\text { trophy. }\end{array}$ \\
\hline
\end{tabular}

\section{Unity in Diversity}

This show carries the idea of unity, equal respect for all religion reflected through the celebration of festivals in the both seasons. The contestants sung songs related to Indian mythological characters that people worship such as Lord Shiva also as Rudra, Lord Ganesha, Lord Shri Rama, Lord Krishna, Lord Hanuman, Goddess Radha, and Goddess Kali, etc. For example, 'O palan hare, nirgun aur niyare', 'Satyam Shivam Sundaram, 'Deva Shree Ganesha Deva', 'Hanuman Chalisa', 'Ram Chandra Keh Gaye Siya Se', 'Yashomati Maaiya se Bole Nandlala', Shirdi wale Sai Baba, and Maula mere Maula, etc. The religious notion of the nation can be count as 'Hindu holy places' and 'faith in Hinduism' in India, but unity in diversity is the main characteristic of this nation (Golwalkar, 1939). According to the format, there is no discrimination on the basis of religion and caste. The images of national identity portrayed through Holi celebration (The festival of colours in India and the message is to spread love without any discrimination). Eid Festival (Known as the "festival of sacrifice"), Birth of Krishna (Hindu Lord), celebrated India as Independence Day, Diwali as a festival of lights, Christmas festival (the birth of Jesus Christ), and welcome of New Year with lots of wishes. The ways of the celebration conveyed the message of joy, love, and peace.
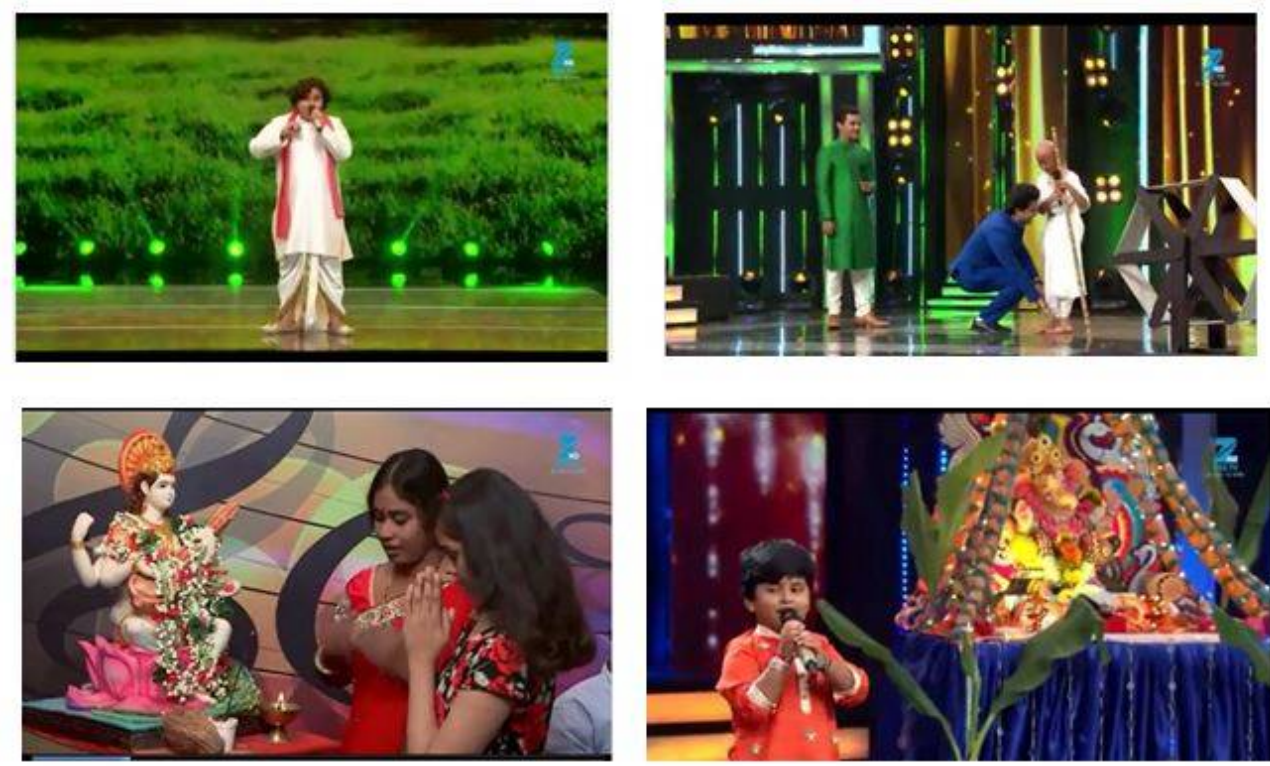

Image 1: Glimpse of “Sa Re Ga Ma Pa” Indian Reality TV Show

There were episodes based on the theme of 'Patriotism' due to the celebration of national days such as Independence Day and Republic Day. For example, the theme was “Jai Jawan Jai Kisan” (Jai Jawan Jai Kisan was a slogan given to India by the Prime Minister of India Lal Bahadur Shastri in 1965 at a public gathering at Ramlila Maidan, Delhi). It is a tradition to sing patriotic songs on a national day 
as the thought that everyone else across the country does the same creates a special bond and a feeling of belonging to one nation.

As a cultural expression, clothing is highly symbolic. By consumption of clothing, the visualization portrayed relationships and it provides the various aspects of conceptualizing the socio-cultural values. In different ceremonies like festival, rituals, dancing, marriage, official engagements clothing become an important marker of national and cultural identity. We have seen the colour combination throughout the performances within the show. The outfits of the contestants were related to the theme of the episodes and songs because clothing also leaves an impression in the viewer's mind. Specifically, if the song is related to national characters then national identity expressed with traditional style because certain items of clothing also signify more national belonging within the show. For clothes produce sensual experiences, ways of moving and feeling, sitting and fiddling, by their 'textility' (Attfield, 200o). Khadi has become a national symbol in the struggle for independence. As per the show's themes, we have seen traditional outfits wore by contestants and other members within the show. These popular symbols can be count as marks of status.

Table 4: Other significant Events in the Show

\begin{tabular}{|l|l|l|}
\hline Sr. No. & "Sa Re Ga Ma Pa L'il Champs" 2017 & "Sa Re Ga Ma Pa 2018" \\
\hline $\mathbf{1 .}$ & Retro special & $\begin{array}{l}\text { Window \#Kiku challenge, in this different } \\
\text { celebrities sung Kishor Kumar (Singer) songs. }\end{array}$ \\
\hline 2. & 9o's songs & 9o's special \\
\hline 3. & Asha Bhosle special & Tribute to Mohd. Aziz \\
\hline 4. & Eid special & Kawali Special \\
\hline 5. & Classic special & Rap special \\
\hline 6. & Diwali special & Christmas \& New Year special \\
\hline
\end{tabular}

\section{Family Values}

A component of family values within Indian culture is accepted by our society. The celebration of Mother's day, Father's day and family special episodes represent the importance of family values. The structure and "quality of relationships" between family members are depicted as a major influence on the well-being of children. The "family relationships" and their links with parent and child represented as a part of the format. The final episodes based largely in part on contestant's families and their feelings about the grand finale. For example how much the winning position matters for them and their families, on the Father's Special' episode songs selected such as 'Bhagon ke har phool ko apna samjhe baghban', 'Apne toh apne hote hain', also the experience shared by fathers, how a father play a vital role to run his family and without telling anyone he only faces all the problems and saves the family. These episodes illustrate the power of family relationships and family have on decision making, and thus illustrate an important aspect of the family values that reside in our cultural values. The purpose of participation has been depicted as the needs of the family such as social, economic, and personal. Each of the contestants in the analysed episodes mentioned being the reasons for their participation, thus illustrating their need and desire for the achievement. As mentioned above, the family values portrayed as a mother-son relationship, father-daughter relationship, and grandparents-grandchildren relationships within the show.

A number of cameras and editing techniques have used to maximize the access awarded to viewers in their observation of authenticity through performances of the self. As Edensor (2002, 69)mentioned, performance is a useful symbol to look at the ways in which identities are enacted 
and reproduced, so the national context of reality television can also be considered as identity performances. Through the cameras, the contestant's performances, their feelings, their thoughts about the challenges, and reactions of parents, and judges used to convey 'reality' to its viewers. We can identify the representation of India as a 'family' through the participation of the contestants from the state namely; Andhra Pradesh, Delhi, Karnataka, Maharashtra, Madhya Pradesh, Odisha, Punjab, Rajasthan, and West Bengal. Cities like Darjeeling, Kolkata, Amritsar, Vishakhapatnam, Mumbai, Bhubaneswar, Faridkot, Bhatinda, Gwalior, Ludhiana, Barmer, etc. The covered location of different states and their cultural expressions through glimpse tries to connect the viewers with national context throughout the whole seasons of the $\mathrm{Sa} \operatorname{Re} \mathrm{Ga} M a \mathrm{~Pa}$ show.
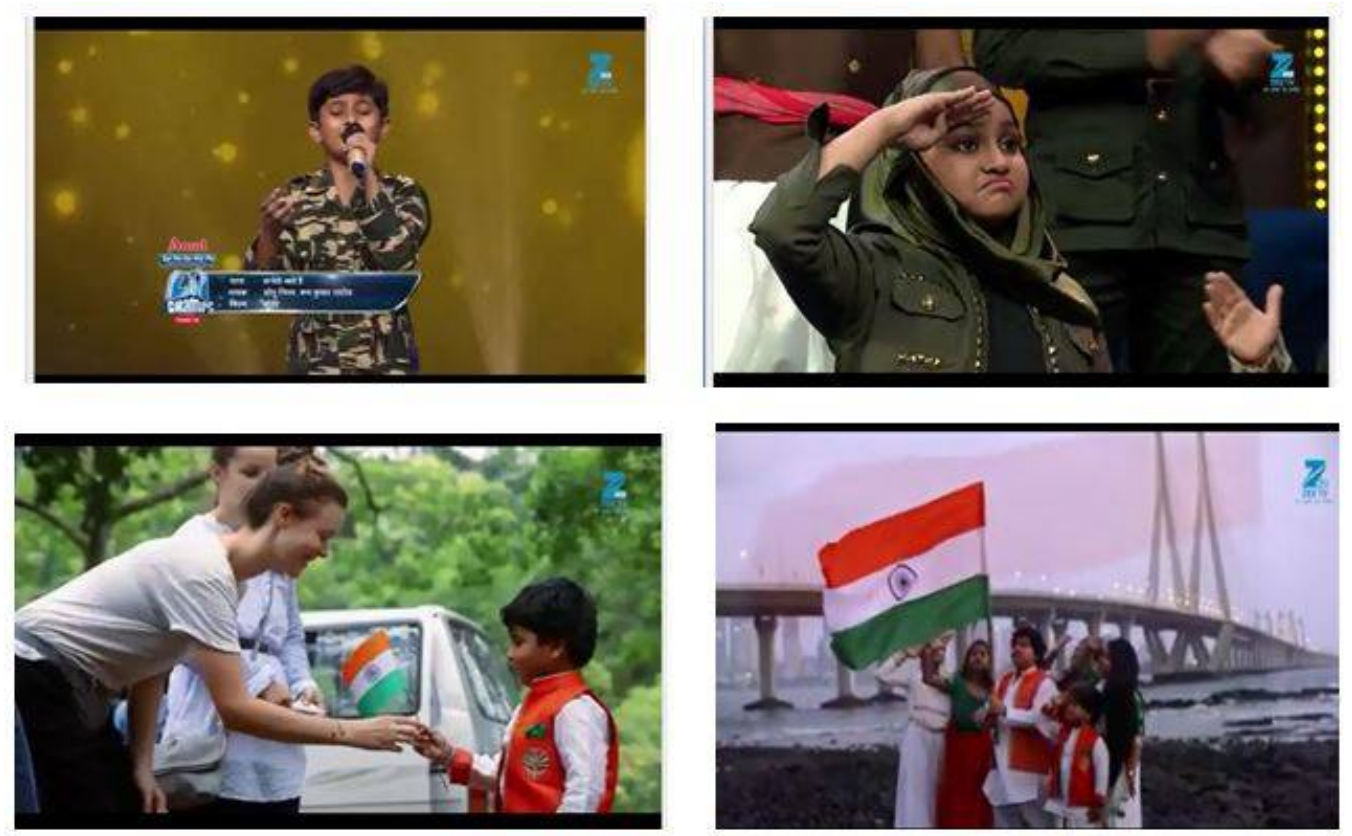

Image2: Glimpse of "Sa Re Ga Ma Pa” Indian Reality TV Show

\section{Analysis from data based on questionnaire}

In the questionnaire which we have received 205 responses from students of media studies (Film and Television), we included questions in Likert scale format that relate to the ideas discussed in our research study. These questions pertain to the perceived features and uniqueness we have observed in Indian singing reality television show. They are: the formats by charting narrative and characters (Q.1), reveals the representation of the nation (Q.2) performed as a cultural medium (Q.3), dynamic with the mix of cultural values, images, symbols, and practices (Q. 4), performances of participants offers cultural expressions to represent national identity (Q.5). In response to these questions, we have received high responses in percentages of strong agreement and agreement from the respondents. They are: Q.1 (14.6\%, 60.5\%), Q.2 (8.8\%, 65.4\%), Q.3 (40.5\%, 47.8\%), Q.4 $(6.3 \%, 52.2 \%)$, and Q.5 (26.3\%, 51.2\%). Question no. 3 and 4 have greater meaning and relevance for our study. It relates that Indian singing reality television shows performed as a cultural medium and a sense of national identity can be dynamic with the mix of cultural values, images, symbols, and practices.

With respect to questions 6-12, we have also got very good responses in the form of strong agreement and agreement from respondents. The questions are; i. we can identify the key ways in 
which the concept of the nation is constructed (Q.6), ii. Traditions and festivals which are inspired by national audiences (Q.7), Sending out a strong message of all-inclusiveness and standing up against discrimination over caste, creed, colour, community, religion, only focuses their spotlights on talent (Q.8), The narrative succeeds in sharing cultural elements (Q.9), The positive association of national identity with cultural expressions (Q. 10), Music with full of hope and energy with the core theme of 'Music for all'. (Q. 11), and carries the idea of pluralism also equal respect to all the religions (Q. 12). (See Table 1)

We found that the questions related to the representation of Indian singing reality television show through narratives, format and performances, we have received a balance response with good agreement and neutral. The results indicate that majority of the respondents shared their agreement by opting agree and neutral that shows larger support for our study to bringing a sense of national identity associated with cultural expressions.

\section{Conclusion}

This paper reveals the structure of Indian singing reality television show in which the national identity is represented through cultural expressions within the $\mathrm{Sa} R e \mathrm{Ga} M a \mathrm{~Pa}$ show format. The relationship that reality television has to 'the real' illustrates the important role that this genre has in communicating understandings of the nation. Through the participation of 'ordinary people' and emphasis on their performances, we can identify some of the ways in which the images of national identity are represented within Indian singing reality television. The analysis of this study offered here, therefore, indicates the ways where the viewers of the society can connect with cultural expressions and represent the nation through the genre of reality television. As Edensor has mentioned that understating the nation is important and national identity is as likely to be identified in television (Edensor, 2002, 141). However, this paper has mainly focused on the narratives there is a multitude of ways in which the nation could be analysed in Indian reality television. Further studies could gather interesting findings by focusing on these representations in a deeper way. In addition, the popularity of Indian singing reality television show format provides an interesting focus for identifying Indian culture within other contexts. Hence, the genre of singing reality television has emerged as an influential cultural medium by its audio-visible presence in India.

\section{References}

Aslama, M., \& Pantti, M. (2007). Flagging Finnishness: Reproducing National Identity in Reality Television. Television E New Media, 8(1), 49-67. https://doi.org/10.1177/1527476406296263.

Attfield, J. (2000). Wild Things: The Material Cultures of Everyday Life. Oxford: Berg.

Bagley, G. (2001). A mixed bag: Negotiating claims in MTV's the real world. Journal of Film and Video, 53 $(2 / 3), 61-76$.

Barker, C. (1999). Television, Globalisation and Cultural Identities. Buckingham: Open University Press.

Barton, K. M. (2009). Reality television programming and diverging gratifications: The influence of content on gratifications obtained. Journal of Broadcasting and Electronic Media, 53 (3), 46o-476.

Bhabha, H. [ed] (1990) Nation and Narration, London: Routledge.

Billig, M. (1995). Banal Nationalism. London: Sage.

Cann, V. (2013). Constructing the nation in reality TV : a comparative study. Continuum: Journal of Media $\mathcal{E}$ 
Cultural Studies, 27(5), 729-739. https://doi.org/10.1080/10304312.2013.772105

Dixit, M. (2013). A Critical Analysis of the Media Practices in India for Television Reality Shows : An Audience Driven Approach Under the Supervision of Dedicated to Avatar Meher Baba.

https://shodhganga.inflibnet.ac.in/handle/10603/124559

Edensor, T. (2002). National Identity, Popular Culture and Everyday Life. Berg.

Fiske, J. (1989). Understanding Popular Culture. London: Unwin Hyman.

George, D., and Paul M. (2003). SPSS for Windows Step by Step: A Simple Guide and Reference 11.o. Update. 4th ed. Boston: Allyn \& Bacon.

Goffman, E. (1974). Frame Analysis. New York. Harper and Row.

Golwalkar, M. S. (1939). We or Our Nationhood Defined. Nagpur: Bharat Publications.

Goode, W. J., and Paul K. Hatt (2006). Methods in Social Research. New Delhi: Surjeet Publications.

Hall, A. (2006). Viewers' perceptions of reality programs. Communication Quarterly, 54 (2), 191-211.

Hill,A. Reality TV Audiences and popular factual television. Routledge. 2005.

Horace M. N., Austin \& Paul M. H. 1983. Television as a cultural forum: Implications for research. Quarterly Review of Film Studies. 8,45-55.

Hutchinson, J. (1994). Cultural nationalism and moral regeneration Nationalism, Oxford University Press. 122-131.

Khanchandani, B. (2018). Impact of soap operas and reality shows on viewers A case study of viewers in the city of Jaipur. http://hdl.handle.net/10603/245241

Klaus, E. \& Luecke, S. (2003). Reality TV - Definition and characteristics of a successful genre family using the example of Reality Soap and Docu Soap. Media and Communication Science, 51 (2), 195-212.

Kumar, T. K. S. (2017). Parental mediation on reality shows content in tamil satellite television channels an experimental study in chennai city and thiruvalluvar district of tamilnadu (Issue May). http://hdl.handle.net/10603/237245

Lundy, L.K., Ruth, A.M., \& Park, T.D. (2008). Simply irresistible: Reality TV consumption patterns. Communication Quarterly, 56 (2), 208-225.

Malko, A. (2013). A study of the reality game show concept "Survivor" - how national identities are represented in a transnational reality format.

Mathur, A. (2014). Television Reality Shows and the Perceptions and Social Attitudes of Rural School Children of National Capital Region: A Critical Study.

N.Boobalakrishnan. (2016). Parental Mediation and their Attitude Towards Children's Television Viewing (Issue April). http://hdl.handle.net/10603/239563

Namjoshi, P. R. (2015). An analytical study of change in the television content appreciation level of Indian television audience of non fiction programs subject to exposure to alternative television content. http://hdl.handle.net/10603/8406o

Nachbar, J., \& Lause, K. (1992). Popular culture: An introductory text. Bowling Green: Bowling Green State University Popular Press.

Newcomb, H.M., \& Hirsch, P. M. (1983). Television as a cultural forum: Implications for research. Quarterly Review of Film Studies. 8,45-55.

Potter, A. (2013). You've been pranked: Reality TV, national identity and the privileged status of Australian children's drama. Media International Australia, 146, 25-34. https://doi.org/10.1177/1329878x1314600106

Price, E. (2010). Reinforcing the myth: Constructing Australian identity in "reality TV." Continuum, 24(3), 451-459. https://doi.org/10.108o/10304311003703157

Priest, S. H. (2009). Doing Media Research: An Introduction. Thousand Oaks, CA: Sage Publications, 2009.

Propp, Vladimir (1968) Morphology of the Folktale. Publications of the American Folklore Society. University of Texas Press. 
Reiss, S. \& Wiltz, J. (2004). Why people watch reality TV. Media Psychology, 6 (4), 363-378.

Sa Re Ga Ma Pa L'il Champs (2017). Essel Vision Productions, 69 episodes. Zee TV, 25th February, 2017-29th October, 2017.

Sa Re Ga Ma Pa (2018), 27th season, Essel Vision Productions, 30 episodes, 13 October 2018 - 27 January 2019.

Smith, A. (1998). Nationalism and Modernism. London: Routledge.

Stewart, M. (2019). Live tweeting, reality TV and the nation. International Journal of Cultural Studies, 23(3), 1-16. https://doi.org/10.1177/1367877919887757

Trivedi, D. A. (2016). Television reality shows and their influence on youth in Gujarat with respect to the broadcasting code of conduct between years 2006 to 2011. http://hdl.handle.net/10603/136687

Thomas C. Davis (1999). Revisiting Group Attachment: Ethnic and National Identity. Political Psychology Vol. 20, No. 1, pp. 25-47.

Turner, G. (2005). Cultural Identity, Soap Narrative, and Reality TV. Television E New Media. 415-422.

Turner, G. 2010. Ordinary People and the Media: The Demotic Turn. London: SAGE.

Willis, P. (1990). Common Culture: Symbolic Work at Play in the Everyday Cultures of the Young. Milton Keynes: Open University Press. 